\title{
Effect of different levels of sucrose on microtuberization and different substrates on minituber production resulted from potato meristem culture
}

\author{
S. Saha ${ }^{1}$, M. Ahmed ${ }^{2 *}$ M. M. Islam ${ }^{2 *}$, R. N. Remme ${ }^{3}$ and M. R. Ali $^{4}$ \\ ${ }^{1}$ (Student, Biotechnology and Genetic Engineering Discipline, Khulna University, Bangladesh) \\ ${ }^{2 *}$ (Professor, Agrotechnology Discipline, Khulna University, Bangladesh) \\ ${ }^{3}$ (Lecturer, Agrotechnology Discipline, Khulna University, Bangladesh) \\ ${ }^{4}$ (Professor, Biotechnology and Genetic Engineering Discipline, Khulna University, Bangladesh)
}

\begin{abstract}
The present research work was undertaken to choose the most effective sugar concentration in in vitro microtuberization from cultured shoot tips and to select the best substrates for minituber production from ex vitro transferred plantlets. Percentage of survivability of microtuber producing plants increased with the increase of sucrose concentration. Best survival rate and average diameter of tuber per plant was found at $10 \%$ sucrose. Minituber production on direct field showed best performance. It was observed that after 30 days, maximum shoot length per plant $(188.87 \mathrm{~mm})$ was found on the direct field whereas the lowest shoot length per plant $(66.81 \mathrm{~mm})$ was on coconut dust. Lowest weight of tuber per plant was also recorded on the substrates containing coconut dust. The highest weight of tuber was found in direct field. In case of, average diameter of tuber per plant, $25 \%$ soil $+75 \%$ coconut dust showed minimum result and on the other hand, in direct field, large size of tubers were found.

Key words: Microtuberization, Minituber, In vitro, Ex vitro, Potato
\end{abstract}

\section{Introduction}

Microtubers ("in vitro" developed tubers) are miniature seed potatoes and they represent an intermediary phase between "in vitro" plantlets and minitubers. Microtubers are the first generation of potato seed from tissue culture, being used to solve the problems of transplanting the plantlets from "in vitro" to "in vivo" conditions. The microtubers offer a lot of advantages to storage, transport and mechanization due to their little size and reduced weight. They can be planted directly in the soil and they can be produced in any period of the year. Microtuber production "in vitro" is very important for producing and storage of valuable seed potato stocks.

Potato microtubers obtained by "in vitro" culture from single-node cuttings are convenient for handling, storage and exchange of a healthy germplasm, representing an important component, along with plantlets and minitubers, for seed potato production programs (Roşu R., 2004). Microtuber production represents in the same time an efficient method for obtaining a healthy material, by which the process of production is reduced with 34 years. The sucrose is the most critical stimulus for tuber induction (Wang, 1982 and Abbott, 1986), as results from the review of Struik (1999), regarding induction, initiation and growth of potato tubers. The high sucrose concentrations are essential for "in vitro" microtuber induction, influencing this process through the osmotic effect and by serving as energy source (Simko I. 1994, Perl A. 1991, Struik PC.1999)

Minitubers are generally produced in the greenhouse in many countries around the world. The source of material is either the plantlets developed inside the growth chamber of tissue culture laboratory or the already produced mini or micro tubers in the greenhouse and in the laboratory, respectively. Greenhouse should be facilitated with temperature, light, humidity and air circulation for the production of minitubers.

In in vivo condition average tuber weight and tuber number were determined as different depending on the production technique (Struik, 1999). Khuri et al., (1995) found that the tuber numbers of various potato cultivars were between 6.2 to 7.9 in plantlets grown in polyethylene bags. Present research work has been undertaken to fulfill the following specific objectives to choose the most effective sugar concentration in in vitro microtuberization from cultured shoot tips and to select the best substrates for minituber production from $e x$ vitro transferred plantlets.

\subsection{Experimental site:}

\section{Materials and Methods}

The experiment was carried out at the Plant Tissue Culture Laboratory of Agrotechnology Discipline, Khulna University, Khulna-9208, Bangladesh, during April 2010 to January 2011. 


\subsection{Type of explants:} production.

In vitro grown potato explants were used as source materials for microtuberization and minituber

\subsection{Constituents of media for microtuberization of potato:}

For microtuber formation, MS medium supplemented with BAP-5.0 mg $1^{-1}$, Chloro Choline Chloride (CCC)-500 $\mathrm{mg} \mathrm{l}^{-1}$ and different concentrations of sucrose- $5 \%, 6 \%, 7 \%, 8 \%, 9 \%, 10 \%$ is used.

\subsection{Substrates used in pots for minituber formation:}

Following substrates were employed for minituber production:

$\begin{array}{lll}\text { 1. } & \text { Soil } & 100 \% \\ \text { 2. } & \text { Sand } & 100 \% \\ \text { 3. } & \text { Coconut dust } & 100 \% \\ \text { 4. Soil : Sand } & 50 \%: 50 \% \\ \text { 5. Soil : Coconut dust } & 25 \%: 75 \% \\ \text { 6. Soil : Coconut dust } & 50 \%: 50 \% \\ \text { 7. Soil : Coconut dust } & 75 \%: 25 \% \\ \text { 8. } & \text { Directly into the field } & \end{array}$

\subsection{Experimental design}

All the experiments were laid out in a Completely Randomized Design (CRD) with five replications for each treatment. In that case, a plastic pot containing different substrates with a single healthy plant was considered as a replication.

\subsection{Procedure for microtuberization}

After taking all the precautions to ensure aseptic condition, in vitro grown healthy plantlets were selected for further inoculation. All inoculation and aseptic manipulations were carried out under a laminar airflow cabinet. planlets were removed carefully and cut the shoot tips measuring $2 \mathrm{~cm}$ in length. Then they were placed onto nutrient media containing test tubes for microtuberization.

After inoculation of the explants, the microtuber induction cultures were incubated in the dark at $24^{\circ} \mathrm{C}$ and relative humidity $65 \%$, maintaining a temperature of $18^{\circ} \mathrm{C}$. Microtuber was first observed at 35 days after inoculation.

The experiment was laid out in a Completely Randomized Design (CRD) with ten replications. A test tube (15 $\mathrm{cm}$ length) containing $15 \mathrm{ml}$ medium with a single shoot tip of potato was considered as a replication.

\subsection{Procedure for minituber production}

For minituber production of potato, in vitro cultured plants were transplanted into plastic pots (4 inch size) with different substrates (soil, sand, coconut dust and their different combination) and some were directly into the field. Soil, sand and coconut dust were autoclaved at $121^{\circ} \mathrm{C}$ for 15 minutes before transplantation. After proper mixing of different substrates according to each treatment, they were kept in plastic pots. Few minutes later after watering, plants were transferred into pots. Transferred plants were placed into growth chamber with $85 \%$ humidity for 24 hours. After that, they were kept in net house.

\subsection{Parameters studied and data collection}

To study the effect of different sugar concentrations on in vitro microtuberization,

$>$ survibility of plant,

$>$ percentage of plant producing microtuber,

$>$ no. of microtuber per plant and

$>$ average diameter of tuber per plant were measured.

After 20 days interval, data were collected.

For experiment of ex vitro minituber production, data were collected by measuring

$>$ percentage of survivability of plants up to 30 days,

$>$ leaf color,

$>$ shoot length per plant,

$>$ no. of tuber per plant,

$>$ average diameter of tuber per plant and

$>$ average weight of tuber per plant.

Leaf color of every plant was observed visually. 


\subsection{Analysis of data}

Recorded data for all of the experiments were analyzed for ANOVA (Analysis of Variance) with the help of computer using MSTAT-C program and the means were compared according to Duncan's Multiple Range Test (DMRT) and Least significance Differences (LSD).

\section{Results and Discussion}

The results of the experiments (Table 1) revealed that the percentage of plants producing microtuber increased with the increase of sucrose concentrations. Percentage of survivability also increased with the increase of sucrose concentration. The highest survival rate $(80 \%)$ was found at $10 \%$ sucrose. The highest number of microtuber was 2.17 observed on $10 \%$ sucrose where as the lowest number was 1.33 at $6 \%$ sucrose. In case of average diameter of tuber plant ${ }^{-1}$, it was observed that $10 \%$ sucrose showed best result. Average diameter of tubers varied from $3.12 \mathrm{~mm}$ to $5.11 \mathrm{~mm}$ irrespective of sucrose concentrations.

Table 1. Effect of different sucrose concentration in presence of BAP $\left(5 \mathrm{mgL}^{-1}\right)$ and $C C C\left(500 \mathrm{mg} \mathrm{L}^{-1}\right)$ on in vitro microtuberization from cultured shoot tips.

\begin{tabular}{|c|c|c|c|c|}
\hline $\begin{array}{l}\text { Sucrose concentration } \\
(\%)\end{array}$ & $\begin{array}{l}\text { Survivability } \\
(\%)\end{array}$ & $\begin{array}{l}\text { Plants producing } \\
\text { microtuber } \\
(\%)\end{array}$ & $\begin{array}{l}\text { No. of microtuber } \\
\text { plant }^{-1}\end{array}$ & $\begin{array}{l}\text { Average diameter of } \\
\text { tuber plant }{ }^{-1} \\
(\mathrm{~mm})\end{array}$ \\
\hline 5 & 50 & 40 & 2 & 3.12 \\
\hline 6 & 50 & 40 & 1.33 & 3.91 \\
\hline 7 & 50 & 50 & 1.5 & 4.44 \\
\hline 8 & 60 & 60 & 2 & 4.50 \\
\hline 9 & 70 & 60 & 2 & 4.62 \\
\hline 10 & 80 & 70 & 2.17 & 5.11 \\
\hline Level of significance & NS & NS & 0.01 & 0.01 \\
\hline LSD & - & - & 1.363 & 2.285 \\
\hline
\end{tabular}

Sucrose has been established as prime component for potato micropropagation (Khuri and Moorby, 1995). There have been several reports comparing the effects on micropropagation of a range of sucrose concentrations and established that 3\% sucrose was the optimum level for in vitro potato micropropagation ( Pruski et al., 2003). For optimal plantlet growth, sucrose level sustainability are necessary and if it is rapidly hydrolyzed into glucose and fructose making the long term maintenance of desirable sucrose level is difficult. The present investigation was tended to find out the effect of sugar level on microtuberization and found that microtuberization increased with the increasing sugar level and the optimum concentration was $10 \%$ sucrose which was dissimilar to Pruski et al., (2003).

B.

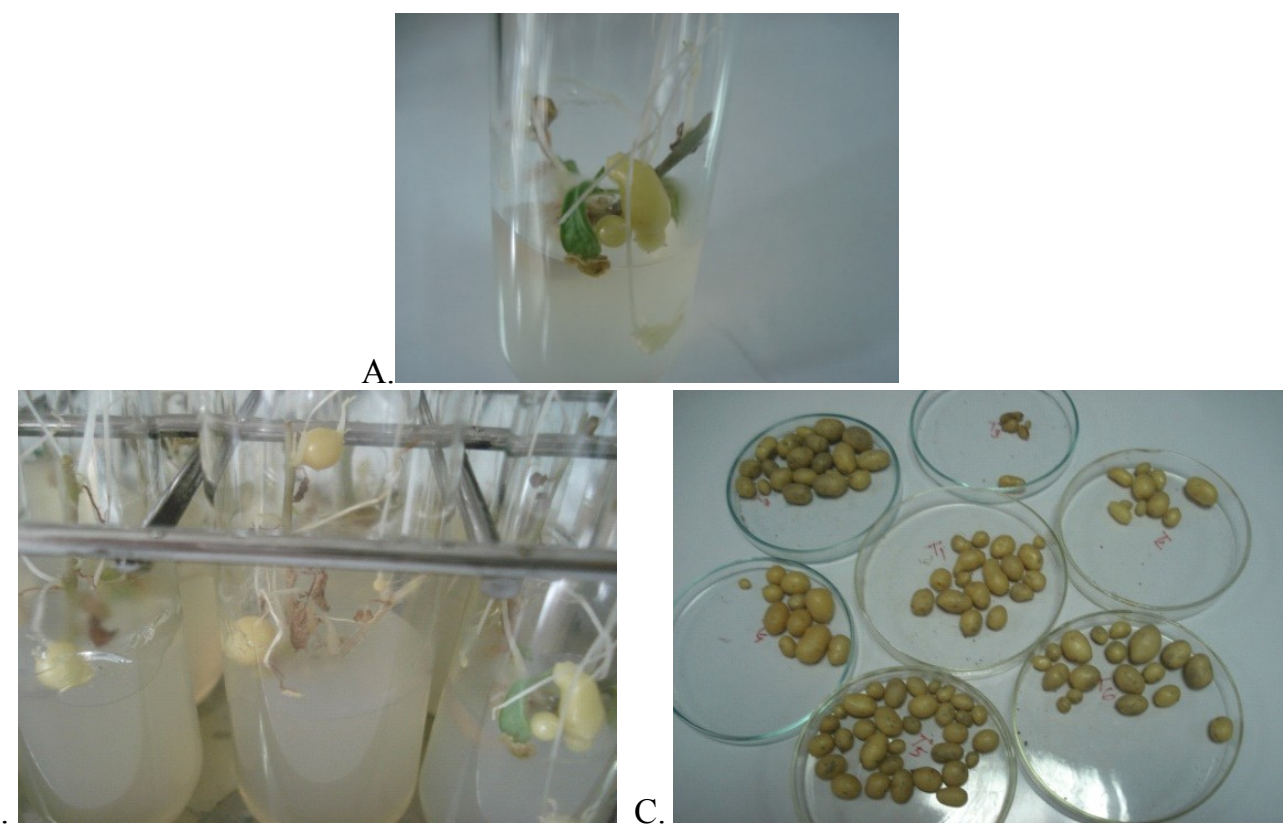

Plate 1. Effect of sucrose on In vitro microtuberization. A. Microtuber formation at $5 \%$ sucrose. B.

Microtuber formation at $10 \%$ sucrose. C. Harvested Microtubers from in vitro grown plantlets.

In vitro grown potato plantlets were carefully removed, washed and planted into different substrates to investigate ex vitro performance of plants and performance of minituber production. Survival rate of plants after 30 days was found similar for all substrates whereas, leaf colors of plants vary from substrates to substrates. 
Minituber production on direct field showed best performance. It was observed that after 30 days, maximum shoot length plant ${ }^{-1}(188.87 \mathrm{~mm})$ was found on the direct field whereas the lowest shoot length plant ${ }^{-1}(66.81$ $\mathrm{mm}$ ) was on coconut dust. Average weight of tuber plant ${ }^{-1}$ varied from $0.77 \mathrm{gm}$ to $6.17 \mathrm{gm}$ irrespective of different substrates. Lowest weight of tuber plant ${ }^{-1}$ was recorded on the substrates containing coconut dust; although soil, sand, coconut dust, $50 \%$ soil $+50 \%$ sand, $25 \%$ soil $+75 \%$ coconut dust, $50 \%$ soil $+50 \%$ coconut dust and $75 \%$ soil $+25 \%$ coconut dust were found statistically similar effective for weight of tuber. The highest weight of tuber was found in direct field. In case of, Average diameter of tuber plant ${ }^{-1}, 25 \%$ soil $+75 \%$ coconut dust showed minimum result and on the other hand, in direct field, large size of tubers were found (Table 2).

Table 2. Ex vitro minituber production using different substrates.

\begin{tabular}{|c|c|c|c|c|c|c|}
\hline Substrates & $\begin{array}{c}\text { Survivability } \\
(\%)\end{array}$ & Leaf color & $\begin{array}{l}\text { Shoot } \\
\text { length }(\mathrm{mm})\end{array}$ & $\begin{array}{l}\text { No. of } \\
\text { tuber plant } \\
-1\end{array}$ & $\begin{array}{l}\text { Average } \\
\text { diameter of } \\
\text { tuber plant }{ }^{-1} \\
(\mathrm{~mm})\end{array}$ & $\begin{array}{l}\text { Average weight } \\
\text { of tuber plant } \\
(\mathrm{gm})\end{array}$ \\
\hline Soil & 100 & Green & $131.76 b$ & $3.4 \mathrm{bc}$ & 15.20 & $2.47 \mathrm{~b}$ \\
\hline Sand & 100 & Yellowish & $69.32 \mathrm{c}$ & $2.0 \mathrm{bc}$ & 15.09 & $1.23 b$ \\
\hline Coconut dust & 100 & Yellowish & $66.81 \mathrm{c}$ & $1.0 \mathrm{c}$ & 12.94 & $0.77 b$ \\
\hline $50 \%$ soil $+50 \%$ sand & 100 & Light green & $95.85 \mathrm{bc}$ & $2.75 b c$ & 14.85 & $1.5 \mathrm{~b}$ \\
\hline $\begin{array}{l}25 \% \text { soil }+75 \% \\
\text { coconut dust }\end{array}$ & 100 & Yellowish & $92.14 b c$ & $4.6 \mathrm{bc}$ & 12.49 & $1.36 \mathrm{~b}$ \\
\hline $\begin{array}{l}50 \% \text { soil }+50 \% \\
\text { coconut dust }\end{array}$ & 100 & Light green & $117.4 b$ & $4.5 \mathrm{bc}$ & 12.53 & $1.63 \mathrm{~b}$ \\
\hline $\begin{array}{l}75 \% \text { soil }+25 \% \\
\text { coconut dust }\end{array}$ & 100 & Green & $135.34 b$ & $5.6 \mathrm{~b}$ & 14.37 & $2.6 \mathrm{~b}$ \\
\hline Direct on field & 100 & Dark green & $188.87 \mathrm{a}$ & $9.4 \mathrm{a}$ & 15.5 & $6.17 \mathrm{a}$ \\
\hline Level of significance & NS & & 0.01 & 0.01 & NS & 0.01 \\
\hline
\end{tabular}

Data in a column followed by same letters are not significantly different according to DMRT.

In in vivo condition average tuber weight and tuber number were determined as different depending on the production technique (Leifert and Struik, 1992; 1999). Keller et al., (2006) found that the tuber numbers of various potato cultivars were between 6.2 to 7.9 in plantlets grown in polyethylene bags. In the study of minituber production, result showed that plants which were directly transplanted into field represented best result than other substrates.
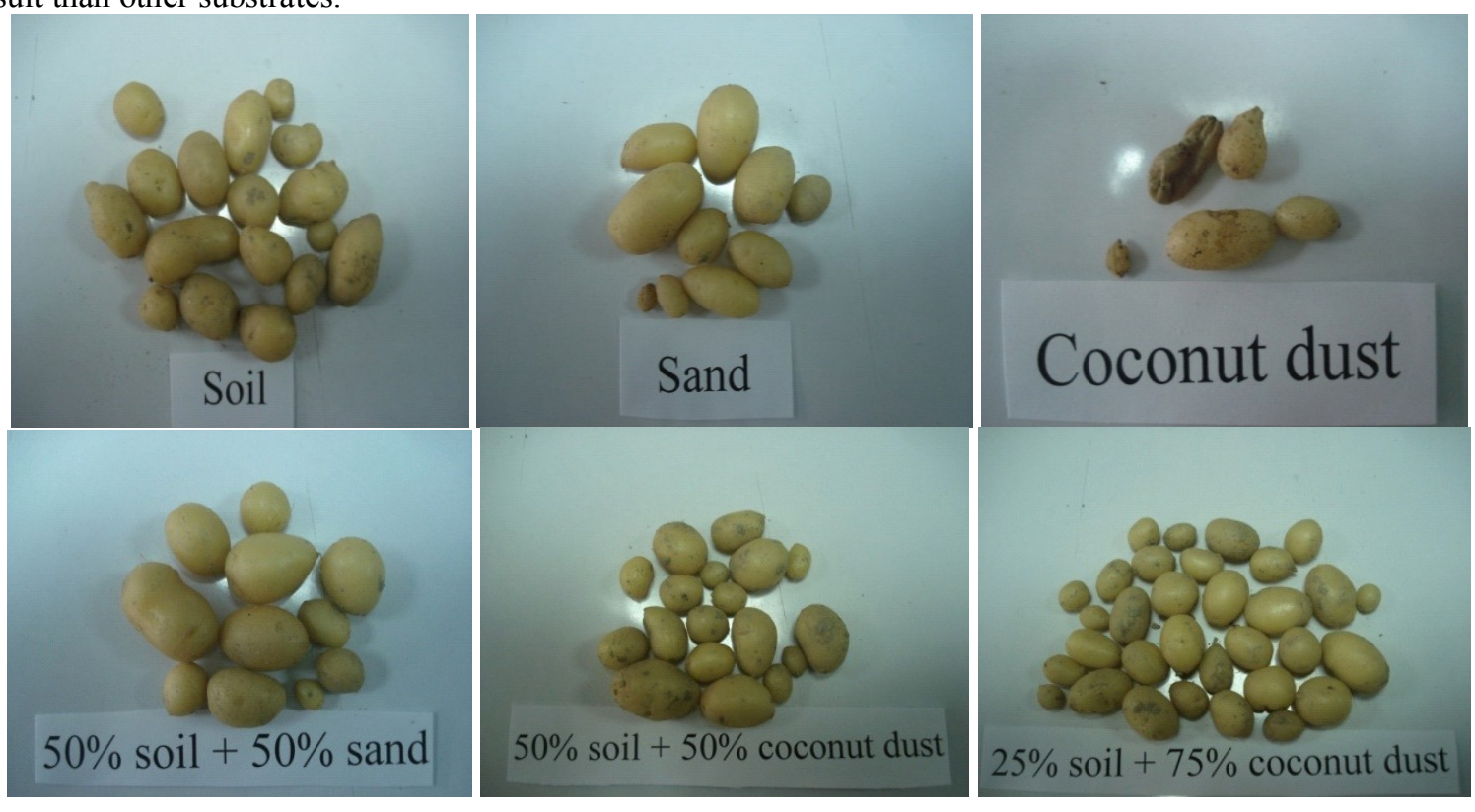

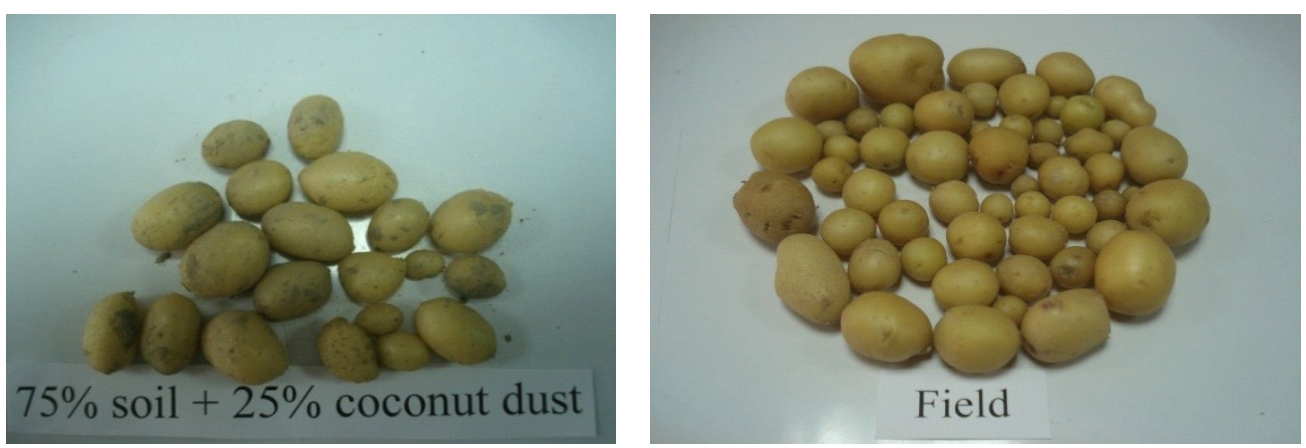

Plate. 2. Minituber formation from different substrates in ex vitro condition.

\section{References}

[1]. Abbott A.J., and A.R. Belcher, 1986. Potato tuber formation in vitro. In: LA Withers, PG Alderson (eds), Plant Tissue Culture and its Agricultural Applications. Butterworths, London, pp.113-122.

[2]. Anonymous, 2000. Potato Seed Certification Standards. Oregon State University, Carvallis, USA

[3]. Keller, E.R.J., A. Senula, S. Leunufna, and M. Grübe. 2006. Slow growth storage and cryopreservation - tools to facilitate germplasm maintenance of vegetatively propagated crops in living plant collections. International Journal of Refrigeration 29:411-417.

[4]. Khuri, S. and Moorby, J., 1995. Investigations into the roles of sucrose in potato cv. Estima microtuber production in vitro. Annals of Botany 75: 295-303.

[5]. Leifert, C., Pryce, S., Lumsden, P.J. and Waites, W.M., 1992. Effect of medium acidity on growth and rooting of different plant species growing in vitro. Plant Cell Tissue and Organ Culture 30: 171-179.

[6]. Perl A., D. Aviv, L. Willmitzer, and E. Galun, 1991. In vitro tuberization in transgenic potatoes harboring B-glucuronidase linked to a patatin promoter: Effect of sucrose levels and photoperiods. Plant Science 73:87-95.

[7]. Pruski, K., Astatkie, T., Duplessis, P., Lewis, T., Nowak, J. and Struik, P.C. 2003. Use of jasmonate for conditioning of potato plantlets and microtubers in greenhouse production of minitubers. American Journal of Potato Research 80: 183-193.

[8]. Roşu R., Chiru N., Rolot J.L., 2004, Researches on genotype influence on potato microtuberization, Anale, INCDCSZ, Vol. XXXI, Tipografia Phoenix Brasov, 120-129.

[9]. Simko I. 1994, Sucrose application causes hormonal changes associated with potato tuber induction. J Plant Growth Reg 13:73-77.

[10]. Struik PC, and SG Wiersema, 1999. Production of pre-basic seed. In: Seed Potato Technology. Wageningen Pers. pp. 173-216.

[11]. Struik, P.C. and S.G. Wiersema, 1999. Seed Potato Technology, p: 383. Wageingen Perss, Wageningen, The Netherlands.

[12]. Wang P., and C. Hu, 1982. In vitro mass tuberization and virus-free seed-potato production in Taiwan. American Potato Journal 59:33-37. 